\title{
METODE ILMIAH \\ DALAM ILMU-ILMU SOSIAL
}

\author{
John Sabari ${ }^{1}$ )
}

\begin{abstract}
Abstrak
Kajian ini bertujuan untuk mengetahui lebih dalam dan komprehensif tentang metode ilmiah dalam studi ilmu-ilmu sosial. Dari telaah kritis yang dilakukan terhadap hubungan obyek-metode diperoleh gambaran, bahwa prosedur kinerjanya ilmiah ilmu-ilmu sosial menggunakan metode linier (persepsi, konsepsi, dan prediksi) dan untuk mengungkap kebenarannya menggunakan metode kuantitatif dan metode kualitatif. Metode kuantitatif dan metode kualitatif dalam studi ilmu-ilmu sosial tidak perlu dipertentangkan secara radikal, namun perlu pemanduan agar hasil yang diharapkan lebih optimal. Dengan kuantitatif, masalah obyektivitas lebih mudah terjaga dan dengan kualitatif, realitas ganda dapat diungkap, lebih sensitif dan adaptif terhadap pola-pola nilai yang diteliti.
\end{abstract}

Kata kunci: Metode Ilmiah, Ilmu-ilmu Sosial

1) John Sabari adalah Dosen Universitas PGRI Yogyakarta. 


\section{Pendahuluan}

Berkembangnya rasionalisme di Eropa mendorong tumbuhnya aliran filsafat positivisme yang bertolak dari prinsip kesatuan ilmu pengetahuan yang terutama didasarkan pada prosedur pokok: observasi/eksperimentasi-formulasi konsep-konsep-verifikasi. Dari dasar tersebut dengan sendirinya semua bidang studi yang tidak memenuhi prosedur pokok ilmu harus dilepaskan dari kategori ini. Metode dasar yang dikembangkan salah satunya nomotetis. Nomotetis tujuan utamanya merumuskan hukumhukum yang berlaku umum (general laws) atau disebut juga generalisasi. Di lain pihak berkembang pula di daratan Eropa sekitar awal abad XIX kelompok Hermeneutika yang pada dasarnya menolak monisme metode dalam ilmu sebagaimana yang dianjurkan kaum Positivis. Mereka menekankan metode ideografis dalam kegiatan keilmuannya. Metode ideografis bertujuan untuk mencapai gambaran-gambaran khusus dari gejala alam terutama yang menyangkut kehidupan manusia. Tujuan akhir kelompok ini adalah bisa mengerti (verstehen) dari gejala, bukan hanya menerangkan (erklaeren) dari gejala-gejala seperti yang dituju oleh kelompok positivisme.

Perdebatan di atas juga merembet pada ilmu-ilmu sosial yang notabene sebagai ilmu pengetahuan lahir belakangan dibandingkan dengan ilmu-ilmu alam. Jujun S.
Suriasumantri menyatakan bahwa dalam performansi keilmuannya, ilmu-ilmu sosial dinilai agak ketinggalan, bahkan ada beberapa ahli berpendapat ilmu-ilmu sosial tidak akan pernah menjadi ilmu dalam arti yang sepenuhnya (1999:135). Salah satu embrio pernyataan tersebut bertolak dari metode ilmiah atau metode keilmuannya dan tentu saja menimbulkan tanda tanya tentang metode ilmiah apa saja yang dipergunakan dalam studi ilmu-ilmu sosial? Oleh karena itu pengkajian ini menarik dilakukan dengan tujuan agar diperoleh pemahaman yang lebih memadai dan komprehensif tentang metode ilmiah dalam studi ilmu-ilmu sosial.

\section{Metode Ilmiah}

Istilah metode secara etimologis berasal dari bahasa Yunani meta yang berarti sesudah dan kata hodos yang berarti jalan. Jadi metode merupakan langkah-langkah yang diambil menurut urutan tertentu, untuk mencapai pengetahuan yang telah dirancang dan dipakai dalam proses memperoleh pengetahuan jenis apa pun (Sri Soeprapto, 2003:128).

Definisi serupa juga disampaikan Gie (1999:117), metode ilmiah adalah suatu prosedurprosedur yang mewujudkan polapola dan tata langkah dalam melaksanakan penelitian ilmiah. Sedangkan menurut Jujun S. 
Suriasumantri (1999:101), metode ilmiah adalah suatu rangkaian prosedur yang tertentu yang harus diikuti untuk mendapat jawaban tertentu dari pernyataan tertentu pula. Ada juga yang mengartikan metode ilmiah sebagai prosedur yang dipergunakan oleh para ilmuwan dalam pencarian secara sistematis terhadap pengetahuan baru dan peninjauan kembali pengetahuan yang telah ada. Sedikit berbeda disampaikan Geoges Kneller (dalam Dadang Suparda, 2008:42). Kneller mendefiniskan metode ilmiah adalah struktur rasional dari penyelidikan ilmiah yang hipotesisnya disusun dan diuji.

Dari pendapat-pendapat di atas dapat ditarik benang merahnya, bahwa metode ilmiah pada hakikatnya merupakan prosedur yang mencakup berbagai kegiatan, pikiran, pola kerja, tata kerja, dan cara teknis untuk memperoleh pengetahuan baru dan mengembangkan pengetahuan yang sudah ada.

Mengenai langkah-langkah dalam metode ilmiah, ternyata belum ada kesatuan paham dari para ilmuwan dan filsuf. Mereka mempunyai pendapat yang berbeda-beda dan memiliki dasar yang kuat untuk metodenya tersebut. Namun dalam konteks ini penulis berusaha untuk mensintesanya dengan mengacu pada pendapat para pakar. Menurut J. Lachman (dalam Dadang Supardan, 2008:43) metode ilmiah mencakup: perumusan hipotesis spesifik atau pertanyaan spesifik untuk menyelidiki, perancangan penyelidikan, pengumpulan data, pengolahan data, penggolongan data dan pengembangan generalisasi, serta pemeriksaan kebenaran. Pendapat serupa disampaikan Gie (1999:111) yaitu metode ilmiah mencakup meng-analisis, mendeskripsikan, mengklasifikasikan, mengadakan pengukuran, memperbandingkan, dan melakukan survei.

Jadi tepat apa yang disampaikan Kaplan (dalam Dadang Supardan, 2008:44), bahwa kebenaran ilmiah itu beragam seiring dengan rentangan fenomena yang perlu dipelajari begitu luas dan kompleks dan tidak tepat bila kita memutlakkan metode ilmiah. Namun kita perlu memedomani metode dalam melaksanakan kinerja ilmiah, sejauh tidak menganggap satusatunya jalan menuju kebenaran ilmiah. Sebab metode ilmiah disini mencakup setiap teknik, metode, strategi penelitian yang digunakan para ilmuwan untuk mencari dan sampai pada sesuatu ataupun penemuan kebenaran ilmiah, sejauh hal itu dapat dipertanggungjawabkan secara empirik. Salah satu metode ilmiah yang dapat dijadikan rujukan adalah pendapat Tyndall (dalam Jujun S. Suriasumantri, 1990:125129) yang dikenal dengan proses logico-hypothetico-verifikasi.

Langkah-langkahnya meliputi:

1) Perumusan masalah 2) Penyusunan kerangka berpikir dalam pengajuan hipotesis 3) Perumusan hipotesis, 4) Pengujian hipotesis, dan 5) Penarikan kesimpulan. Langkahlangkah tersebut dapat dibagankan seperti di bawah ini. 


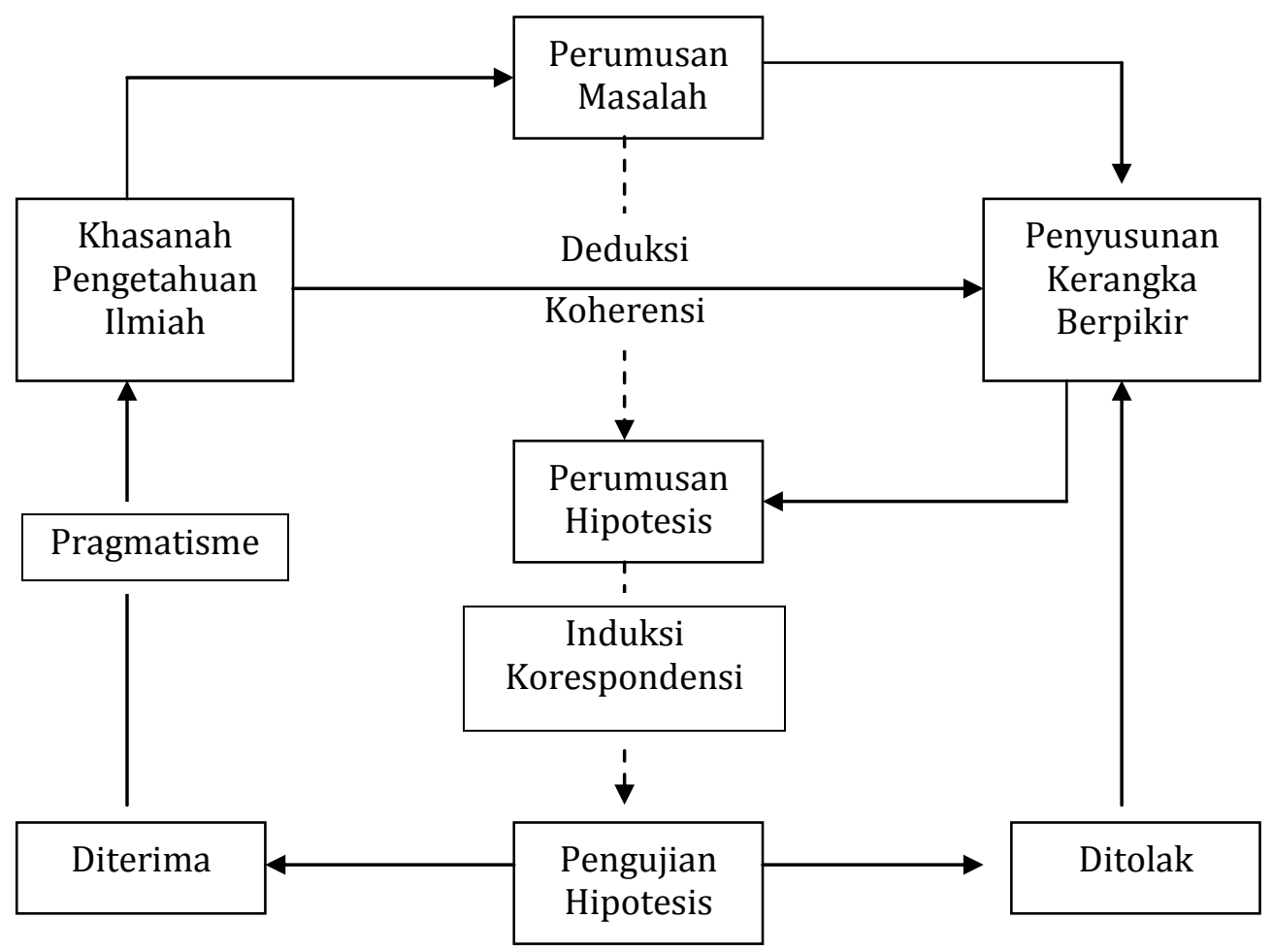

Lebih lanjut Jujun S. Suriasumantri (1999:105) menyampaikan ada enam kerangka dasar prosedur ilmiah, yaitu:

1. Sadar akan adanya masalah dan perumusan masalah

2. Pengamatan dan pengumpulan data yang relevan

3. Penyusunan dan klasifikasi data

4. Perumusan hipotesis

5. Deduksi dan hipotesis

6. Tes dan pengujian kebenaran (verifikasi) dari hipotesa.

Kesadaran dan perumusan masalah. Adanya kondisi kejiwaaan (sadar) pada diri para ilmuwan, bahwa dunia terdiri dari fakta dan kejadian yang terpisah-pisah dan banyak jumlahnya. Ketika manusia menemukan beberapa kesulitan dalam menghadapi dunia secara akal, maka manusia menciptakan masalah dan mengajukan sesuatu pertanyaan yang menurut alam pikirnya dapat dijawab.

Pengamatan dan pengumpulan data. Tahap ini merupakan sesuatu yang paling dikenal dalam metode ilmiah, dikarenakan banyaknya kegiatan ilmiah yang diarahkan pada pengumpulan data. Sehingga banyak orang yang menyamakan keilmiahan dengan pengumpulan fakta. Pengamatan dapat dilakukan secara langsung dan tidak langsung, bahkan fakta yang teliti dimungkinkan dapat dilaksanakan dengan bantuan alat yang dibuat manusia dengan metode ilmia.

Penyusunan dan klasifikasi data. Tahap ini menekankan dalam pe- 
nyusunan fakta dalam kelompokkelompok, jenis-jenis dan kelaskelas. Dalam cabang-cabang ilmu, usaha untuk mengidentifikasi, menganalisasi, membandingkan dengan fakta-fakta yang relevan disebut taksonomi.

Perumusan hipotesis. Hipotesis merupakan pernyataan sementara tentang hubungan antara variabel. Hubungan ini diajukan dalam bentuk dugaan kerja atau teori yang merupakan dasar dalam menjelaskan kemungkinan hubungan tersebut.

Deduksi dan hipotesis. Hipotesis sebagai langkah penyusunan pernyataan yang logis yang menjadi dasar untuk menarik kesimpulan atau deduksi mengenai hubungan variabel-variabel tertentu yang diselidiki. Hipotesis dapat menolong peneliti dalam memberikan ramalan dan menemukan fakta yang baru.

Tes dan verifikasi hipotesis. Pengujian kebenaran ilmu berarti mengetes alternatif-alternatif hipotesis dengan pengamatan kenyataan yang sebenarnya atau melalui eksperimen. Jika fakta tidak mendukung satu hipotesis, maka hipotesis yang lain dipilih dan diproses ulang. Hakim yang terakhir menurut kaum empirisme adalah data empiris yaitu kaidah yang bersifat umum/hukum/generalisasi haruslah memenuhi persyaratan pengujian hipotesis. Sedangkan menurut kaum rasionalis, hipotesis hanya baru dapat diterima secara keilmuan apabila konsisten dengan hipotesis-hipotesis sebelumnya yang telah disusun dan teruji kebenarannya.
Dengan demikian dapat dikatakan, bahwa metode itu ada hubungannnya dengan suatu prosedur, proses, atau teknik yang sistematis dalam penyelidikan suatu ilmu tertentu untuk mendapatkan objek (bahan) yang diteliti. Hal ini berarti ada hubungannya dengan metodologi. Menurut Webster (dalam Helius Syamsudin; 2007:1314) yang dimaksud metodologi adalah:

a. Suatu keseluruhan (body) metodemetode, prosedur-prosedur, konsep-konsep kerja, aturanaturan, dan postulat-postulat yang digunakan oleh ilmu pengetahuan, seni, atau disiplin...

b. proses, teknik-teknik, atau pendekatan-pendekatan dalam pemecahan suatu masalah atau di dalam mengerjakan sesuatu; suatu atau seperangkat prosedurprosedur...

c. dasar teoritis dari suatu dokrin filsafat: premis-premis dan konsep-konsep dasar dari suatu filsafat ...

d. suatu ilmu atau kajian metode ... menganalisis prinsip-prinsip atau prosedur-prosedur yang harus menuntun penyelidikan dalam suatu bidang (kajian) tertentu.

Metodologi ini secara umum didefinisikan sebagai suatu cabang filsafat yang berhubungan dengan ilmu tentang metode atau prosedur, suatu sistem tentang metode-metode atau aturan-aturan yang digunakan dalam ilmu pengetahuan (Helius Syamsudin, 2007:14).

Sebenarnya metode dan metodologi adalah dua fase kegiatan yang berbeda untuk tugas yang sama. 
Sartono Kartodirjo menyatakan metode sebagai "bagaimana orang memperoleh pengetahuan" (how to know) dan metodologi sebagai "mengetahui bagaimana orang memperoleh pengetahuan" (to how to know) (1992: ix). Dalam kaitannya dengan studi ilmu-ilmu sosial, dengan sendirinya metode ialah "bagaimana orang memperoleh ilmuilmu sosial", sedangkan metodologi ialah "mengetahui bagimana orang memperoleh ilmu-ilmu sosial". Hal ini mengandung maksud bagaimana menggunakan menggunakan istilah pada tempat seharusnya. Kita harus mengetahui prosedur-prosedur apa yang harus ditempuh dalam kegiatan ilmiah. Penguasaan metode dan metodologi bagi ilmuwan ibarat penguasaan ketrampilan tukang tembok dan penalaran serta kiat seorang insinyur bangunan. Seorang tukang tembok mengetahui dan menguasai metode membangun rumah tanpa harus menguasai teori dan perhitungan-perhitungan yang rumit. Tetapi seorang insinyur bangunan harus menguasasi metodologi (tentu saja termasuk metode) pembangunan rumah. Ia merencanakan semua dari awal seperti pembuatan blue print perhitungan konstruksi dan kekuatan bangunan, kenyamanan, keamanan, sampai pada hubungan rumah dengan lingkungan sekitar. Jadi seorang ilmuwan ilmu-ilmu sosial profesional dituntut penguasaan sekaligus metode dan metodologi disiplinnya.

\section{Studi Ilmu-Ilmu Sosial}

Ilmu pengetahuan dalam dinamikanya dapat diklasifikasi menjadi beberapa kategori. Menurut Taufik Abdullah (2006:33-34), ilmu terbagi dalam dua kategori besar, yaitu ilmu eksakta dan non eksakta. Khusus ilmu non eksakta dipilah menjadi dua: ilmu humaniora dan ilmu sosial. Ilmu yang berkaitan dengan filsafat, sastra, seni, dan bahasa dikategorikan dalam ilmu humaniora, sedangkan di luar itu adalah ilmu sosial. Pendapat serupa disampaikan Helius Syamsudin (2007:272), bahwa pengetahuan manusia (human knowledge) umumnya dapat diklasifikasikan atas tiga kelompok besar, yaitu ilmu-ilmu alamiah (natural sciences), ilmu-ilmu sosial (social sciences), dan ilmu-ilmu kemanusiaan (humanities). Ilmu alamiah mengkaji lingkungan hidup manusia, ilmu sosial mengkaji manusia dalam hubungannya dengan manusia-manusia lainnya, dan ilmuilmu kemanusiaan mengkaji manivestasi-manivestasi (eksistensi) kejiwaan manusia.

Sebagaimana disinggung di atas, bahwa ilmu-ilmu sosial adalah ilmu yang mempelajari manusia dalam hubungannya dengan manusiamanusia lainnya. Definisi serupa disampaikan Taufik Abdullah (2006:31), ilmu sosial adalah ilmu yang mempelajari perilaku manusia dalam kehidupan bersama. Sedangkan Dadang Supardan (2008:34-35) menyampaikan ilmu sosial (social science) adalah ilmu yang mempelajari perilaku dan aktivitas sosial dalam kehidupan bersama. Jadi yang 
dimaksud ilmu-ilmu sosial (social sciences) adalah kelompok disiplin ilmu yang mempelajari aktivitas manusia dalam hubungannya dengan sesamanya.

Obyek material dari studi ilmuilmu sosial adalah berupa tingkah laku dalam tindakan yang khas manusia, ia bersifat bebas dan tidak bersifat deterministik, ia mengandung: pilihan, tanggung jawab, makna, pernyataan privat dan internal, konvensi, motif dan sebagainya (Tim Dosen Filsafat Ilmu, 2007:4). Aktivitas manusia tersebut termasuk berpikir, bersikap, dan berperilaku dalam menjalin hubungan sosial diantara sesamanya dan bersifat kondisionalitas. Dengan kata lain obyek tersebut sebagai gejala sosial. Gejala sosial memiliki karakteristik fisik namun diperlukan penjelasan yang lebih dalam untuk mampu menerangkan gejala tersebut, sebab tidak hanya mencakup fisik tetapi juga aspek sosiologis, psikologis, maupun kombinasi berbagai aspek.

Menurut Wallerstein (dalam Dadang Supardan, 2008:34) yang termasuk disiplin ilmu sosial adalah sosiologi, antropologi, ekonomi, sejarah, psikologi, ilmu politik, dan hukum. Sedangkan menurut Robert Brown dalam karyanya Explanation in Social, ilmu-ilmu sosial meliputi: sosiologi, ekonomi, sejarah, demografi, ilmu politik, dan psikologi (Taufik Abdullah, 2006:33). Meskipun terdapat perbedaan pendapat tentang apa yang disebut ilmu sosial, namun semuanya mengarah kepada pemahaman yang sama, bahwa ilmu sosial adalah ilmu yang mempelajari perilaku dan aktivitas sosial dalam kehidupan bersama. Ilmu sosial dalam perkembangannya kemudian lahir berbagai spesialisasi disiplin ilmu-ilmu sosial, seperti: ilmu komunikasi, studi gender, dan lain-lain.

Secara umum ilmu pengetahuan yang termasuk dalam kelompok disiplin ilmu-ilmu sosial adalah:

1. Sosiologi adalah disiplin ilmu yang mempelajari tentang masyarakat dalam hubungan-hubungan antara orang-orang dalam masyarakat tersebut (interaksi sosial, kelompok sosial, gejalagejala sosial, organisasi sosial, struktur sosial, proses sosial maupun perubahan sosial) (Soerjono Soekanto, 2006: 17-21).

2. Antropologi adalah studi tentang manusia yang berusaha menyusun generalisasi yang bermanfaat tentang umat manusia dan perilakunya, dan untuk memperoleh pengertian ataupun pemahaman yang lengkap tentang keanekaragaman manusia (Koentjaraningrat, 1986: 1-2).

3. Ilmu Geografi adalah the science of places, concerned with qualities an potentialities of countries (Vidal dela Blache dalam Dadang Supardan. 2008:227). Dalam pandangan ilmuwan geografi, secara sederhana geografi merupakan disiplin akademik yang terutama berkaitan dengan penguraian dan pemahaman atas perbedaan-perbedaan kewilayahan dalam distribusi lokasi di permukaan bumi, fokusnya pada lingkungan, tata ruang, dan tempat. 
4. Ilmu Sejarah adalah ilmu yang yang berusaha untuk mendapatkan pengertian tentang segala sesuatu yang telah dialami (termasuk yang diucapkan, dipikirkan dan dilaksanakan) oleh manusia di masa lampau yang bukti-buktinya masih dapat ditelusuri/diketemukan masa sekarang (Widja, 1988:8).

5. Ilmu Ekonomi adalah ilmu yang mempelajari usaha manusia untuk memenuhi kebutuhannya dalam mencapai kemakmuran yang diharapkan, dengan memilih penggunaan sumber daya produksi yang sifatnya terbatas (Samuelson dan Nordhaus, 1990: 5).

6. Psikologi adalah ilmu mengenai proses perilaku dan proses mental (Dadang Supardan, 2008:425).

7. Ilmu Politik adalah ilmu yang mempelajari masalah-masalah kekuasaan dalam kehidupan bersama atau masyarakat. Masalahmasalah kekuasaan itu menyangkut proses penentuan tujuan-tujuan dari sistem yang ada dan melaksanakan apa yang menjadi tujuan (Miriam Budihardjo, 1986: 8).

\section{Metode Ilmiah dalam Studi Ilmu- ilmu Sosial}

Mengkaji metode ilmiah dalam studi ilmu-ilmu sosial tidak lepas dari sifat-sifat objeknya. Sebagaimana disinggung di atas, bahwa masing-masing ilmu mempunyai objek formalnya sendiri dan metode yang digunakan didasarkan pada susunan dan hukum-hukum seperti yang ada pada obyek tersebut (Tim Dosen Filsafat Ilmu UGM, 2007:130131). Berdasarkan hubungan obyekmetode ini, maka untuk memahami metode ilmiah dalam ilmu-ilmu sosial harus dipahami ciri-ciri dasar yang berlaku dalam objek ilmu tersebut. Objek ilmu-ilmu sosial adalah aspek-aspek tingkah laku manusia yang dapat diamati dan dinalar sebagai suatu fakta empiris, tetapi sekaligus termuat didalamnya arti, nilai, dan tujuan. Hal ini senantiasa terkait dengan kenyataan, bahwa manusia berbeda dengan binatang, benda-benda fisik lainnya. Manusia sebagai keseluruhan melampaui status obyek-obyek yang ada disekitarnya. Oleh karena itu pendekatannya dengan cara analog: setiap lingkungan masyarakat "sama" namun dalam "kesamaannya" itu juga berbeda. Sehingga titik pangkalnya peneliti tidak berada di luar obyek penelitian, dengan kata lain subyek terlibat dalam penelitian tentang sesamanya.

Menurut Rickman (dalam Tim Dosen Filsafat Ilmu UGM, 2007:133), metode ilmiah dalam ilmu-ilmu sosial meliputi hal-hal yang diperbuat manusia dalam dunianya dan yang dipikirkan dalam dunianya tersebut. Ilmu-ilmu sosial mempunyai karakteristik normatifteleologis dengan metode linier dan analisisnya untuk menemukan arti, nilai, dan tujuan. Metode linier memiliki tiga tahap yaitu:

1. Persepsi, yaitu penangkapan data melalui indera. 
2. Konsepsi, yaitu pengolahan data dan penyusunannya dalam suatu sistem.

3. Prediksi, yaitu penyimpulan dan sekaligus peramalan.

Persepsi sebagai konstruk dalam ilmu-ilmu sosial tidak semudah ilmu-ilmu alam, karena gejala sosial lebih bervariasi dibandingkan dengan gejala fisik. Sehingga tidak semua gejala sosial dapat diamati secara langsung. Hal ini mengingat gejala sosial banyak yang bersifat unik (kondisionalitas ada jalinan unsur-unsur kejadian sosial) dan sukar untuk berulang lagi, bahkan mungkin tidak akan pernah berulang. Oleh karena itu ahli sosial tidak bersikap sebagai penonton yang menyaksikan suatu proses kejadian sosial, tetapi menjadi bagian integral dari obyek kehidupan yang ditelaahnya.

Konsepsi yang ingin dicapai dari ilmu-ilmu sosial adalah mendapatkan pengertian yang mendalam dari gejala-gejala yang sedang diselidiki dengan Verstehen (teknik dalam menemukan dan hipotesis), maupun dengan berpartisipasi dari peneliti. Untuk sampai pada pengertian yang mendalam dalam ilmu-ilmu sosial menurut Max Weber (dalam Jujun S. Suriasumantri, 1999:145) dapat dikatakan:

... upamanya tentang martir keagamaan, maka hal itu haruslah lewat pengertian para martir tersebut. Untuk memahami sedalamdalamnya tentang martir dan untuk mengesahkan hipotesis tentang martir dalam lingkup sosial budaya mereka, jika kita ingin menangkap apakah arti semua ini bagi para martir, maka kita harus membayangkan kita sendiri sebagai martir...

Metode di atas merupakan khas ilmu-ilmu sosial, dimana dalam menjelaskan peristiwa tidak sebatas wujud fisik/gerak dari suatu peristiwa, tetapi juga pikiran-pikiran yang ada dibalik peristiwa itu. Jujun S. Suriasumantri (1990:132-133) mengatakan, bahwa metode ilmiah dalam studi ilmu-ilmu sosial dikembangkan dengan teknik-teknik tersendiri dalam melakukan kegiatannya. Teknik-teknik tersebut bersifat khusus dan biasanya dikembangkan untuk meneliti aspek tertentu yang bersifat eksploratoris yang bertujuan menemukan pola atau struktur secara keseluruhan. Pendekatan dalam teknik tersebut seringkali dikenal dengan pendekatan holistik. Selain pendekatan holistik dalam studi ilmu-ilmu sosial juga ada pendekatan partiacularistik. Pendekatan particularistik dan holistik digunakan untuk mengungkap universalitas dan kekhususan sebagai bagian dari kebenaran ilmiah ilmu-ilmu sosial ini.

Untuk mengungkapkan hal tersebut di atas, maka dipergunakan metode kuantitatif (posivistik) dan metode kualitatif (naturalistik). Dalam tradisi kualitatif, peneliti harus menggunakan diri mereka sebagai instrumen, mengikuti asumsi-asumsi kultural sekaligus mengikuti data. Untuk mencapai wawasan imajinatif responden, peneliti diharapkan fleksibel dan 
reflektif tetapi tetap menjaga jarak. Sedangkan dalam tradisi kuantitatif, instrumen merupakan alat yang telah ditentukan sebelumnya dan tertata dengan baik sehingga tidak banyak memberi peluang bagi fleksibilitas, masukan imajinatif dan reflektifitas Brannen (2005:11). Metode kuantitatif untuk menelaah manusia dalam hubungannya dengan lingkungannya secara matematis, baik melalui teknik sosiometri maupun skala atau statistik. Sedangkan metode kualitatif digunakan untuk mendapatkan makna-makna yang terkandung didalam hubungan manusia dalam hubungannya dengan manusia-manusia lainnya atau yang ada dibalik kenyataan yang teramati. Contohnya dalam menerangkan dan teknik pengumpulan data tentang terjadinya tsunami jelas akan berbeda dengan teknik pengumpulan data mengenai motivasi seseorang menjadi pekerja seks komersial, dan lain sebagainya.

Terlepas dari kekurangan/ kelemahannya, metode kualitatif dan metode kuantitatif sudah memberi konstribusi positif dalam perkembangan ilmu-ilmu sosial. Untuk itu dalam perkembangan dewasa ini ada upaya memadukan keduanya metode tersebut agar hasil yang agar hasil yang didapat lebih optimal. paradigma kedua metode tersebut tidak perlu dipertentangkan secara radikal karena keduanya saling mengisi (Brannen, 2005:1-50).

Masalah masalah prediksi dalam ilmu-ilmu sosial tidak lepas dari obyektivitas dan generalisasi. Obyektivitas dalam kegiatan ilmuilmu sosial, sering timbul problema, manakala bagian-bagian dari kegiatan sosial dihubungkan dengan subyektivitas dalam interpretasi fakta. Ilmu dikatakan obyektif karena ilmu mendekati fakta-faktanya secara metodis, artinya prosedur ilmiah yang dikembangkan oleh subyek yang mengenal. Misalnya ilmu-ilmu alam berhasil menyalurkan pengaruh subyektif, sehingga terbentuk ilmu yang benarbenar intersubyektif. Namun ilmuilmu sosial dalam praktiknya tidak dapat melakukan eksperimen secara netral. Misalnya tidak bisa uji coba terlebih dahulu pelbagai bentuk sosial. Walaupun hal itu diperlukan, namun bukan itu arah satu-satunya. Arahnya menuju kemanusiaan yang lebih baik dan utuh.

Hal lain juga terjadi dalam membuat generalisasi. Biasanya ilmuwan sosial tidak menjadikan generalisasi sebagai tujuan utama. Mereka lebih memusatkan perhatian pada usaha untuk menerangkan, kemudian mengartikan jalan yang sebenar-benarnya dari peristiwa khusus, yaitu kejadian-kejadian dalam dimensi waktu, tempat serta kondisi-kondisi tertentu. Memang acapkali juga diketemukan pernyataan-pernyataan ilmuwan sosial yang bernada menekankan kebenaran umum dari disamping kekhususan. Contohnya tentang kajian "revolusi", selain mengkaji dari masing-masing revolusi seperti Revolusi Prancis, Revolusi Amerika, Revolusi Rusia dan lain-lainnya, perlu juga dibuat generalisasi untuk memperoleh kebenaran umum. Akan tetapi penilaian yang bersifat kebenaran umum ini berbeda dengan 
membuat generalisasi yang terjadi pada ilmu (science), terutama apa yang dihasilkan tidak berlaku untuk seluruh jaman dan segala situasi dan kondisi. Jadi ilmu-ilmu sosial pada dasarnya tidak asing dengan usaha merumuskan kebenaran umum itu, tapi kelihatannya perumusan tersebut tidak bisa dipisahkan dengan usaha menekankan hal yang berlaku khusus.

Apabila kita memasalahkan generalisasi dalam ilmu-ilmu sosial, maka kita akan berhubungan dengan masalah yang menyangkut ciri lain dari ilmu yaitu prediksi. Secara umum dapat dikatakan, bahwa ilmuilmu sosial karena tidak mengutamakan generalisasi seperti dalam ilmu alamiah, juga kurang memperhatikan prediksi sebagai tujuan akhir dari kegiatan studi sosial. Malah beberapa ilmuwan sosial praktis menegaskan, bahwa begitu ilmuwan sosial berpikir untuk melakukan prediksi, dia hakekatnya berhenti sebagai ilmuwan sosial. Namun demikian tidak menutup kemungkinan untuk melakukan "generalisasi dan prediksi". Dengan membuat generalisasi, meskipun sifatnya terbatas, sedikitnya dapat memberikan apa yang disebut tuntutan-tuntutan umum bagi tindakan-tindakan di masa datang, yang meskipun bukan merupakan prediksi spesifik, bisa juga dianggap valid dan bermanfaat. Memang ilmuilmu sosial tidak mungkin meramalkan peristiwa-peristiwa spesifik sebab sesuatu yang spesifik itu sifatnya unik dimana elemen dari kejadian itu ikut mewarnainya.
Dari gambaran di atas, kiranya dapat dipahami bahwa dalam studi ilmu-ilmu sosial ada yang sebagian yang cenderung memperhatikan unsur generalisasi, tetapi tingkat penggunaannya tidak sama. Ada semacam spektrum nilai dari madzab yang unik kepada filsuf ilmu-ilmu sosial. Seperti di Amerika Serikat misalnya dibedakan adanya madzab yang unik, madzab dengan generalisasi yang sangat terbatas, madzab interaktif, madzab komperatif dan madzab nomothetis. Secara umum dianggap bisa dibedakan antara aliran deskriptif yang lebih cenderung membuat generalisasi yang sangat terbatas atau membuat tetapi tanpa kesadaran) dan aliran teoritis (yang menekankan generalisasi) di lingkungan studi ilmu-ilmu sosial.

Guna memperoleh gambaran yang lebih detil, maka perlu kiranya penulis menyampaikan metode penelitian dipergunakan oleh ilmuilmu yang termasuk dalam kelompok disiplin ilmu-ilmu sosial sebagai berikut:

\section{Sosiologi}

Menurut Soerjono Soekanto (2006:42-45) dan Dadang Supardan (2008: 91-93), metode ilmiah yang umum dipakai para sosiolog diantaranya:

a. Metode Deskriptif

Metode deskriptif adalah suatu metode yang berupaya untuk mengungkapkan pengejaran atau pelacakan pengetahuan. Metode ini dirancang untuk menemukan apa yang 
terjadi, tentang siapa, dimana, dan kapan.

b. Metode Eksplanatori

Metode ini merupakan bagian dari metode empiris. Metode ini lebih menekankan pada upaya menjawab mengapa dan bagaimana.

c. Metode Historis Komparatif

Metode ini menekankan pada analisis peristiwa-peristiwa masa silam untuk merumuskan prinsipprinsip umum, yang kemudian digabungkan dengan metode komparatif, dengan menitik beratkan pada perbandingan antara berbagai masyarakat beserta bidangnya untuk memperoleh perbedaan dan persamaan serta sebab-sebabnya. Dari perbandingan itu dapat dicari petunjuk perilaku kehidupan masyarakat pada masa lalu dan sekarang beserta perbedaan tingkat peradaban satu sama lainnya.

d. Metode Fungsionalisme

Metode ini bertujuan untuk meneliti fungsi lembaga-lembaga kemasyarakatan dan struktur sosial dalam masyarakat. Substansinya, bahwa unsur-unsur yang membentuk masyarakat memiliki hubungan timbal balik yang saling mempengaruhi dan masing-masing memiliki fungsi tersendiri dalam masyarakat.

e. Metode Studi Kasus

Metode studi kasus merupakan suatu penyelidikan mendalam dari suatu individu, kelompok, atau institusi untuk menentukan variabel itu dan hubungan diantara variabel mempengaruhi status atau perilaku yang saat itu menjadi pokok kajian.

f. Metode Survei

Metode survei adalah cara untuk memperoleh data dari populasi yang relatif besar untuk menentukan keadaan, karakteristik, pendapat, dan populasi sekarang yang berkenaan dengan satu variabel atau lebih.

\section{Antropologi}

Antropologi dalam kinerjanya menggunakan pendekatan kuantitatif (posivistik) dan kualititatif (naturalistik). Artinya, dalam antropologi dapat dilakukan secara statistik, baik dilakukan untuk mengukur pengaruh maupun korelasi antar variabel penelitian, dan dapat juga dilakukan secara kualitatif.

Adapun metode yang digunakan yaitu deskriptif, komparatif, studi kasus, etnografi, dan survei. Dari sekian metode yang paling menonjol dan menjadi ciri kas antropologi adalah metode komparatif (Koentjaraningrat, 1986:9). Metode komparatif antropologi adalah metode yang mencabut unsur-unsur kebudayaan dari konteks masyarakat yang hidup dan dibandingkan sebanyak mungkin dengan unsurunsur dan aspek-aspek suatu kebudayaan. Dalam penggunaan metode ini, diidentifikasikan persamaan-persamaan dan perbedaannya secara mendalam. Macam penelitian komparatif sedikitnya ada empat, yaitu: 1) yang bertujuan menyusun sejarah kebudayaan manusia; 2) yang bertujuan untuk 
menggambarkan suatu proses kebudayaan; 3) yang bertujuan untuk taksonomi/klasifikasi kebudayaan, dan; 4) yang bertujuan untuk menguji korelasi-korelasi antar unsur, antar pranata, dan antar gejala kebudayaan, untuk membuat generalisasi mengenai tingkah laku manusia pada umumnya.

\section{Ilmu Geografi}

Dalam kajian geografi menurut R. Bintarto dan Surastopo Hadisumarno (1979:12) ada tiga pendekatan yang sering digunakan, yaitu pendekatan analisis keruangan, analisi ekologi, dan analisis kompleks wilayah. Adapun metode-metodenya sebagai berikut:

a. Metode Deskriptif

Metode ini untuk mendapatkan penjelasan, baik yang bersifat alamiah maupun insaniah dengan mengungkap karakteristik, eksploratif, hubungan fungsional, dan dampak dari suatu fenomena atau peristiwa.

b. Metode Eksperimen dan Korelasi

Metode ini berkaitan dengan justifikasi, keyakinan pada keteraturan statistik merupakan bukti adanya hubungan sebab akibat empiris. Pengukuran dan manipulasi data menggantikan posisi penjelasan verbal dan kartografis sebagai prosedur dalam ilmu geografi.

c. Metode ex Post Facto

Metode ini untuk melihat dan mengkaji hubungan antara dua variabel atau lebih, dimana variabel yang dikaji telah terjadi sebelumnya atau tidak diberi perlakuan khusus.

\section{Ilmu Sejarah}

Untuk menggambarkan permasalahan yang diselidiki, mencari sumber tentang fakta historis, meringkas dan mengevaluasi sumber-sumber historis, dan menyajikan fakta-fakta dalam suatu cerita, metode yang dipergunakan adalah metode historis yang mencakup: 1) heuristik (pengumpulan jejak-jejak); 2) kritik dan analisis sumber (kritik sejarah internal dan eksternal); 3) interpretasi fakta, dan; 4) penulisan sejarah (historiografi) (Widja, 1988: 18-25).

\section{Ilmu Ekonomi}

Untuk memenuhi kebutuhan yang bersifat tidak terbatas dengan alat pemenuhan kebutuhan barang dan jasa yang terbatas menurut Samuelson dan Nordhous (1990:610) metode-metode yang digunakan meliputi:

a. Metode Induktif

Metode ini untuk mendapatkan sesuatu keputusan dilakukan dengan mengumpulkan semua data informasi yang ada dalam realita kehidupan. Realita tersebut mencakup setiap unsur kehidupan yang dialami individu, keluarga, dan masyarakat. Contohnya upaya menghasilkan dan menyalurkan sumber daya ekonomi. Upaya tersebut dilakukan sedemikian rupa sampai diperoleh barang dan jasa yang tersedia pada jumlah, harga, dan waktu yang tepat bagi pemenuhan kebutuhan tersebut. Untuk itu, 
maka perlu metode penyusunan daftar kebutuhan sejumlah barang dan jasa yang diperlukan masyarakat.

b. Metode Deduktif

Metode ini berusaha menetapkan cara pemecahan masalah sesuai dengan acuan, prinsip, hukum yang ada dalam ilmu ekonomi. Contohnya dalam ilmu ekonomi terdapat hukum, jika persediaan barang dan jasa berkurang, sementara permintaan tetap, maka harga akan naik. Bertolak dari hukum itu, maka perlu tindakan menjaga agar persediaan barang dan jasa selalu mencukupi kebutuhan masyarakat.

c. Metode Matematika

Metode ini digunakan untuk memecahkan masalah-masalah ekonomi dengan cara pemecahan soal-soal matematis. Maksudnya dalam matematika terdapat kebiasaan yang dimulai dengan pembahasan dalil-dalil. Melalui dalil-dalil tersebut dipastikan bahwa kajiannya dapat diterima secara umum.

d. Metode Statistika

Metode ini dipergunakan untuk bahan menentukan cara yang tepat dalam mengatasi masalah-masalah ekonomi dengan cara pengumpulan pengolahan, analisis, penafsiran dan penyajian data dalam bentuk angka-angka secara statistik.

\section{Psikologi}

Metode yang dipakai psikologi sebagai metode kerjanya menurut
Dadang Supardan (2008: 440-446) sebagai berikut:

a. Metode Eksperimen

Metode ini menekankan pada pengkajian setiap variabel (bebas dan terikat) dengan memberikan perlakuan terhadap kelompok eksperimen, kemudian diukur pengaruhnya perlakuan tersebut.

b. Metode Pengamatan (Observasi)

Metode ini dilakukan untuk mengamati sampel penelitian, baik perilaku binatang maupun manusia yang merupakan titik tolak psikologi.

c. Metode Survei

Metode ini digunakan untuk mendapatkan data secara langsung melalui wawancara atau kuesioner dengan sejumlah sampel yang banyak.

d. Metode Tes

Metode ini dilakukan untuk mengukur segala jenis kemampuan, minat, sikap, dan hasil kerja.

e. Metode Riwayat Hidup dan Kasus

Metode ini dimaksudkan untuk mengungkap kasus-kasus yang ditelaah sesuai dengan kebutuhan penelitian. Sebagian besar riwayat kasus dipersiapkan dengan cara merekonstruksikan riwayat hidup seseorang didasarkan pada kejadian catatan yang teringat.

\section{Ilmu Politik}

Menurut Iswara (1974:5) metode politik secara umum dapat dikelompokkan menjadi dua, yaitu metode induktif dan metode deduktif. Metode induktif diartikan sebagai serangkaian strategi atau prosedur penarikan kesimpulan 
umum yang diperoleh berdasarkan proses pemikiran yang khusus ke yang umum. Sedangkan metode deduktif makna kebalikan dari metode induktif. Metode tersebut mencakup:

a. Metode Deskriptif

Merupakan prosedur pengkajian masalah-masalah politik untuk memberikan gambaran terhadap kenyataan yang ada sekarang secara akurat.

b. Metode Analisis

Merupakan penelaahan secara mendalam terhadap masalah-masalah politik yang disusun secara sistematis dengan memperlihat hubungan fakta satu dengan lainnya.

c. Metode Evaluatif

Merupakan serangkaian usaha penelaahan fenomena politik yang bersifat menentukan terhadap fakta yang dikumpulkan dengan dasar pada norma-norma atau ide-ide abstrak.

d. Metode Klasifikasi

Merupakan penggolongan objek-objek secara teratur yang mesing-masing menunjukkan hubungan timbal balik.

e. Metode Perbandingan

Merupakan metode kajian politik yang menitik beratkan pada studi persamaan dan perbedaan atas dua objek yang dikaji, dengan maksud untuk memperdalam keilmuan.

\section{Penutup}

Metode ilmiah merupakan suatu prosedur, proses, atau teknik yang sistematis dalam penyelidikan suatu ilmu tertentu dengan mengikuti suatu struktur logis kinerja ilmiah. Pola umum dalam metode ilmiah mencakup penentuan masalah, perumusan hipotesis, pengumpulan data, penarikan kesimpulan, dan verifikasi.

Studi ilmu-ilmu sosial adalah ilmu yang mengkaji perilaku dan aktivitas sosial dalam kehidupan bersama. Adapun obyek ilmu-ilmu sosial berupa aspek-aspek tingkah laku manusia yang dapat diamati dan dinalar sebagai suatu fakta empiris, tetapi sekaligus termuat didalamnya arti, nilai, dan tujuan. Ilmu-ilmu sosial berkembang-terspesialisasi dan secara umum yang termasuk dalam ilmu-ilmu sosial adalah sosiologi, antropologi, geografi, sejarah, ekonomi, psikologi, dan politik.

Dari hubungan obyek-metode, maka prosedur kinerjanya ilmiah ilmu-ilmu sosial menggunakan metode linier (persepsi, konsepsi, dan prediksi) dan untuk mengungkap kebenarannya menggunakan metode kuantitatif dan metode kualitatif. Metode kuantitatif dan metode kualitatif dalam studi ilmu-ilmu sosial tidak perlu dipertentangkan secara radikal, namun perlu pemanduan agar hasil yang diharakan lebih optimal.

Mengingat metode kuantitatif dan kualitatif masing-masing memiliki kelebihan dan kelemahan, maka para peneliti perlu kiranya menggunakan inter-metode dalam kinerjanya. 


\section{Daftar Pustaka}

Dadang Supardan. 2008. Pengantar Ilmu Sosial Sebuah Kajian Pendekatan Struktural. Jakarta: PT Bumi Aksara.

Gie, The Liang. 1999. Pengantar Filsafat Ilmu. Yogyakarta: Liberty.

Helius Syamsudin. 2007. Metodologi Sejarah. Yogyakarta: Ompak.

Heri Santoso dan Listiyono Santoso. 2003. Filsafat Ilmu Sosial Ikhtiar Awal Pribumisasi Ilmu-ilmu Sosial. Yogyakarta: Gama Media.

I Gde Widja. 1988. Pengantar Sejarah Dalam Perspektif Pendidikan. Semarang: Satya Wacana.

Iswara, F. 1974. Pengantar Ilmu Politik. Bandung: Dwiantara.

Jujun S. Suriasumantri. 1990. Filsafat Ilmu Sebuah Pengantar Populer. Jakarta: Sinar Harapan.

--------. 1999. Ilmu Dalam Perspektif Sebuah Kumpulan Karangan Tentang Hakikat Ilmu. Jakarta: Yayasan Obor Indonesia.

Koentjaraningrat. 1986. Pengantar Ilmu Antropologi. Jakarta: Aksara Baru.

Miriam Budiardjo. 1986. Dasar-Dasar Ilmu Politik. Jakarta: PT Gramedia.

R. Bintarto dan Surastopo Hadisumarno. 1979. Metode Analisis Geografi. Jakarta: Lembaga Penelitian Pendidikan dan Penerangan Ekonomi dan Sosial.

Samuelson, Paul A. Dan William D. Nordhaus. 1990. Ekonomi Jilid 1. Jakarta: Erlangga.
Sartono Kartodirdjo. 1999. Pendekatan Ilmu Sosial Dalam Metodologi Sejarah. Jakarta: PT Gramedia Pustaka Utama.

Soerjono Soekanto. 2006. Sosiologi Suatu Pengantar. Jakarta: PT Rajagrafindo Persada.

Sri Soeprapto. 2003. Metode Ilmiah dalam Tim Dosen Filsafat Ilmu Fakultas Filsafat UGM. Filsafat Ilmu Sebagai Dasar Pengembangan Ilmu Pengetahuan. Yogyakarta: Liberty.

Taufik Abdullah. 2006. Ilmu Sosial dan Tantangan Zaman. Jakarta: Raja Grafindo Persada.

Tim Dosen Filsafat Ilmu Fakultas Filsafat UGM. 2007. Filsafat Ilmu Sebagai Dasar Pengembangan Ilmu Pengetahuan. Yogyakarta: Liberty. 